\title{
駅階段空間における手すり照明の適用可能性に関する研究 \\ A STUDY ON APPLICABILITY OF HANDRAIL LIGHTING IN STAIRS SPACE OF RAILWAY STATION
}

\author{
許載 永 ${ }^{* 1}$, 内田陽子 ${ }^{* 2}$, 鄭 敬 宣 ${ }^{* 2}$, \\ 小㟝美希*3, 古賀誉 章*4, 平手 小太郎*5 \\ Jaeyoung HEO, Yoko UCHIDA, Kyungsun CHUNG, \\ Miki KOZAKI, Takaaki KOGA and Kotaroh HIRATE
}

\begin{abstract}
The first purpose of this study is to clarify the influence of light environment on user's evaluations of stairs such as visibility and easiness of moving up and down. By measuring illuminance, brightness, and subjective evaluations of stairs of stations, it shows that illuminance and brightness of the lower view angle influence greatly on subjective evaluations. Taking that result, we conclude that lighting set in handrails of stair can illuminate most efficiently.

The second purpose is to clarify the influence of variation of lighting height. Intended for elderly people and young people, we conducted an experiment. As a result, variation of height of handrail lighting does not influence on subjective evaluations greatly. However, the evaluations in the environment of handrail lighting tend to be higher than that of ceiling lighting. In addition, it shows that elderly people can feel security in the environment of handrail lighting.
\end{abstract}

\section{Keywords : Handrail lighting, Glare, Power saving, Elderly, Lighting design} 手すり照明, グレア, 節電, 高齢者, 照明設計

\section{1. はじめに}

\section{1 社会的背景}

2011 年 $3 \cdot 11$ 大震災による原子力発電所の被害などにより、施設 内電力の節電運営が公共施設を中心に行われた 1)。このような節電 運営は、多くの人が利用する交通施設の駅空間でも活発に行われて おり 2)3)、特に駅空間の消費エネルギーの中で最も大きな部分を占め ている照明エネルギー4)からの節電が注目されている。

照明エネルギーの節電方法としては、照明の一部点灯などの一時 的な方法が採用されていたが、 2020 年までの公共施設全照明の高効 率照明化 5) という政策などにより、照明の LED 化 6)など、より根本 的な解決のための積極的な節電方法が注目されている。

\section{2 建築学的背景}

駅舎を構成している空間の大部分は建築基準法の圈外であり 7)、 駅空間の照明設計においては基本的に JIS 照度基準によっている。

その JIS 照度基準は、1958 年制定 ${ }^{8}$ された以来、1964 年に駅舎 の照度基準が追加 10)され、社会や環境の変化により今まで 6 回改正 された ${ }^{8)}$ 14)。

しかし、駅舎の照度基準の場合、1964 年制定の以来、基準值その
ものは変わらず 10) 14)、約 60 年間の駅空間の環境変化が十分に反映 されていないという問題点がある。

特に、駅舎の階段の場合は制定時点から現在まで通路と同様な空 間として見なされており 11) 15)、ホームとコンコースを慗げる動的な 空間の特性や細長く狭い構造的な特性などが考慮されていないと考 えられる。

\section{3 研究目的}

近年、バリアフリー化が進み、階段での昇降移動をより快適かつ 容易にするためにエスカレーターやエレベーターの設置が盛んに行 われているが、設置するためのスペースや台数が限られているなど の理由から、依然として階段を利用する頻度も高く、階段の安全性 や快適性などについて検討することは重要なことである。

本研究では、駅空間の階段を対象とし、単に節電効果だけに集中 した断片的な照明計画ではなく、定量的・定性的な両面を考慮した 改善を目指し、階段の安全性や視認性に着目した手寸り照明の現場 への適用可能性を検討した上、その性能を利用者の年齢層および滞 在人数による影響から検証することを主な目的とする。

\footnotetext{
*1 東京大学大学院工学系研究科建築学専攻 特任研究員・博士 (工学)

*2 元 東京大学大学院工学系研究科建築学専攻 大学院生・修士 (工学)

*3 拈茶の水女子大学基幹研究院自然科学系 助教 ·博士 (工学

*4 宇都宮大学地域デザイン科学部建築都市デザイン学科 准教授・博士 (工学)

* 5 東京大学大学院工学系研究科建築学専攻 教授·工博
}

Researcher, Dept. of Architecture, Graduate School of Eng., The Univ. of Tokyo, Dr.Eng.

Former Grad. Student, Dept. of Architecture, Graduate School of Eng., The Univ. of Tokyo, M.Eng.

Assist. Prof., Faculty of Core Research, Natural Science Division, Ochanomizu University, Dr.Eng.

Assoc. Prof., Faculty of Regional Design, Dept. of Architecture and Urban Design, Utsunomiya Univ., Dr.Eng.

Prof., Dept. of Architecture, Graduate School of Eng., The Univ. of Tokyo, Dr.Eng. 


\section{2. 駅空間の階段光環境の実態調査}

\section{1 対象駅の概要}

駅空間の光環境の現状を検討するために、2013 年、全照明の LED 化工事が行われた都内の 3 駅を対象とし、改修前後に分けて現場実 測調查を行った。

調查の内容としては照度、輝度などの物理量の実測および同地点 での印象評価（被験者：改修前後各 15 名・14 名、評価時期：日没 後）を行い、印象評価の結果を中心に光環境の現状を把握すること にした。

被験者の場合、改修前（男: 7 名、女: 8 名)、改修後 (男: 7 名、 女：7 名）の設定であり、男女比を均等にし、年齢層は 20 代から 50 代までとし、通常の駅利用者からの評価を行うこととした。

\section{2 印象評価の方法および結果}

印象評価の項目に関しては、「空間全般」に対しての評価(明るさ、 好み、安心感、にぎやかさ、開放感、落ち着き、まぶしさ）７項目、 「光」に対しての評価（あたたかみ、やわらかさ） 2 項目、照明に 対しての評価（適切さ） 1 項目、そして段差の「見やすさ」の構成 とし、両極 7 段階尺度と単極 4 段階尺度を評価尺度として適用した。 なお、評価方法に関しては、評価地点を階段の上り口と下り口に 分け、下から見上げた場合と上から見下ろした場合の評価傾向を両 方検討することとした。改札内に階段がない駅を除く、本章での検 討対象とした階段（階段 1、階段 2) の全景は Fig. 1 の通りである。

階段 1 はホームの広い幅の階段のみの構造であり、ホームに設置 されている線光源に依存している光環境である。階段 2 は階段 1 に 比べ幅の狭い構造であり、壁面を照らす照明方式を採用などにより 階段 1 に比心゙明るい光環境となっている。しかし、両方とも下から 見上げた場合、ホームに設置されている照明器具の光源が直接に目 に入ってしまう問題がある。

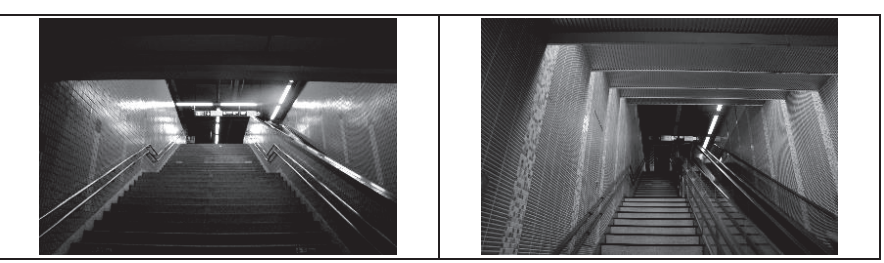

Fig. 1 Full view of stairs 1 and 2

印象評価の結果、改修後の評価結果が全般的に高くなっており、 その中で特徵のある単極 4 段階尺度の「落ち着き」、「まぶしさ」、 照明の「適切さ」、段差の「見やすさ」結果の平均值をピックアップ すると Fig. 2 の通りである。

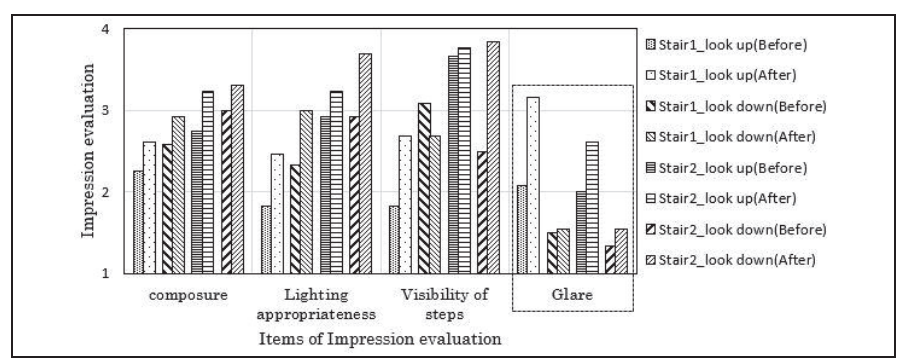

Fig. 2 Problems of Stair Lighting Environment at LED Application
階段 $1 \cdot 2$ をそれぞれ見上げ（上)、見下げ（下）に分け、さらに 改修前（前）、改修後（後）に分けて検討を行った結果、空間照明環 境の変化（蛍光灯 $\rightarrow$ LED 照明）により、空間印象の全般が上昇する ことがわかった。

しかし、高輝度の LED 照明を採用したため「まぶしさ」も上昇 しており、このような照明環境は快適な階段利用の妨げになると考 えられる。

\section{3 階段照明環境の現状}

階段は細長い構造で、天井高が不規則であり、場合によっては天 井面がない空間も存在しており、照明設置位置が制限される空間で ある。そのため、照明器具の位置が壁面や低い天井面となっており、 光源が直接に目に入ることで、グレアが発生しやすい環境である。

なお、一般的な照明手法である天井照明の環境では、階段を利用 する人や壁面などの構造物などにより、影が発生しやすいため、階 段段部の照度分布が不均等となり、上下移動時の安全性に影響があ ると考えられる。

\section{3. 室内実験 1}

\section{1 手すり照明の製作}

本研究では、階段での「安全性」「視認性」、節電」を同時に満 足させる照明方式として、階段の段部を明るく照らすとともに均等 な照度分布の光環境の構成ができる LED 手すり照明を製作した。

\section{2 実験の概要}

実験の条件（Pattern）の構成は Table1 の通りである。天井照明 (メディアインターナショナル株式会社製、色温度 4000K、9W、 $8201 \mathrm{~lm} 、 6$ 個）と手すり照明（株式会社遠藤照明製、色温度 $4000 \mathrm{~K}$ 、 $14301 \mathrm{~m}$ 、調光器付き ERX9358C, ERX9362C、3.5mのフレキシブ ルテープライト 2 個）の性能比較を基本とし、手すり照明の場合、 明るさ $(50 \mathrm{~lx} \cdot 100 \mathrm{~lx} \cdot 200 \mathrm{~lx})$ や設置高さ $(500 \mathrm{~mm} \cdot 800 \mathrm{~mm} \cdot 1,100$ $\mathrm{mm}$ ）を各 3 段階に分け、200lx 単一条件の天井照明を含め合計 10 条件を実験条件として構成した。

Table1 Configuration of the experimental pattern

\begin{tabular}{|c|c|c|c|}
\hline Patterns & $\begin{array}{l}\text { Lighting } \\
\text { System }\end{array}$ & $\begin{array}{c}\text { Installation } \\
\text { Height } \\
\text { [mm] }\end{array}$ & $\begin{array}{c}\text { Setting } \\
\text { Illuminance } \\
{[\mathrm{lx}]}\end{array}$ \\
\hline Pattern 0 & Ceiling lighting & - & 200 \\
\hline Pattern1 & \multirow{9}{*}{$\begin{array}{l}\text { Handrail } \\
\text { lighting }\end{array}$} & \multirow{3}{*}{500} & 50 \\
\hline Pattern2 & & & 100 \\
\hline Pattern 3 & & & 200 \\
\hline Pattern4 & & \multirow{3}{*}{800} & 50 \\
\hline Pattern5 & & & 100 \\
\hline Pattern6 & & & 200 \\
\hline Pattern7 & & \multirow{3}{*}{1,100} & 50 \\
\hline Pattern8 & & & 100 \\
\hline Pattern9 & & & 200 \\
\hline
\end{tabular}

実験対象の階段および照明器具の設置位置の詳細情報は Fig.3 の 通りであり、1,484mm の幅の 11 段構成の階段での評価を行った。 


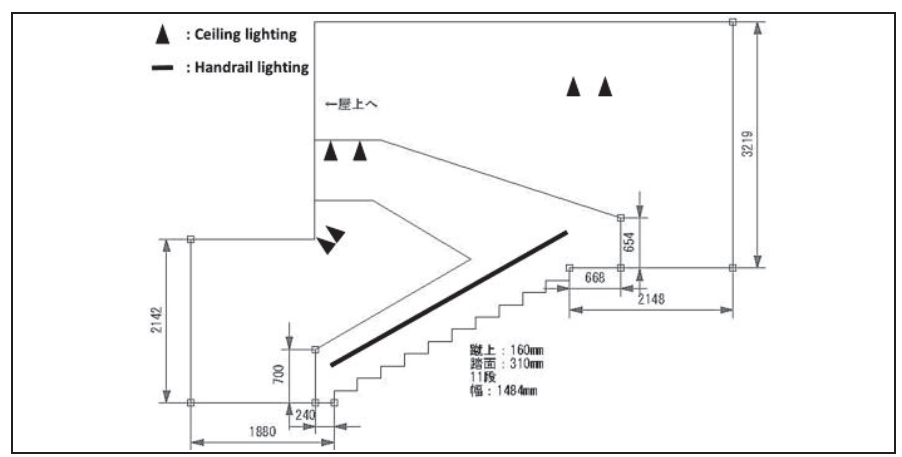

Fig. 3 Full view of the stairs

明るさの場合、JIS 照度基準上の $\mathrm{A}$ 級駅舎の階段照度基準 (200lx) や B 級駅舎（1001x）の基準に基づいて設定し、節電を考慮した低 照度 $(501 \mathrm{x})$ 条件を含め 3 段階の構成とした。

手すり照明の設置高さの場合、通常の手すりの高さ $(1,100 \mathrm{~mm})$ や手すりの 2 段構成の場合の下段の高さ $(800 \mathrm{~mm})$ を基準とした上、 段部をより明るく照らせる $500 \mathrm{~mm}$ 条件を含め 3 段階の構成とした。

被験者の構成は、正常視力の通常の利用者を想定した $20 \sim 30$ 代 の「若年者」グループ 20 人、老化による視力減退の交通弱者を想 定した高齢者グループ（65 歳以上） 20 人の合計 40 人で、年齢層に よる評価特性の検討を行った。

なお、設定された実験室の風景 $(200 \mathrm{~lx}$ の条件 $0 \cdot 3 \cdot 6 \cdot 9)$ は

Fig. 4 の通りである。

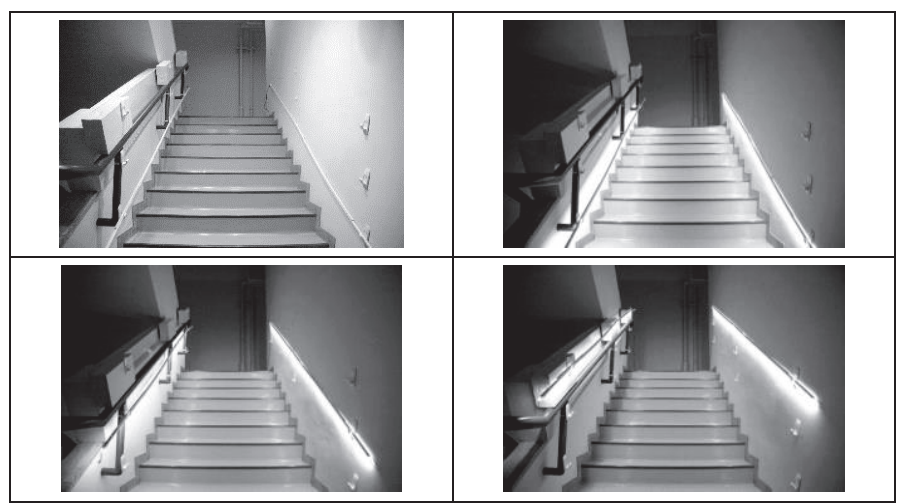

Fig. 4 Image of experiment pattern(Pattern 0, 3, 6, 9)

\section{3 実験の結果 \\ (1) 物理量実測結果}

各条件の設定の上、条件ごとの平均床面照度を以下のように測定 した（Table2）。各段の中央部を含め、500 mm 間隔で右左の 2 列の 照度を測定し、合計 3 列 36 点の照度を平均した值である。各条件 の照度設定上、中央列の照度の平均值が設定照度となっているため、 手すり照明の設置高さが低い $500 \mathrm{~mm}$ の条件の場合、全体平均が小 幅に高くなっている。

Table2 The measured illuminance of each pattern

\begin{tabular}{|c|c|c|c|}
\hline Patterns & $50 \mathrm{~lx}$ & $100 \mathrm{~lx}$ & $200 \mathrm{x}$ \\
\hline Ceiling lighting & - & - & $192 \mathrm{l} x$ \\
\hline Handrail lighting $500 \mathrm{~mm}$ & $69 \mathrm{~lx}$ & $136 \mathrm{l} x$ & $256 \mathrm{l} x$ \\
\hline Handrail lighting $800 \mathrm{~mm}$ & $57 \mathrm{~lx}$ & $110 \mathrm{x}$ & $217 \mathrm{l} x$ \\
\hline Handrail lighting $1,100 \mathrm{~mm}$ & $52 \mathrm{~lx}$ & $102 \mathrm{l} \mathrm{x}$ & $2001 \mathrm{x}$ \\
\hline
\end{tabular}

天井照明の条件（条件 0：2001x） と手寸り照明の条件（条件 9： 200lx、1,100mm）の各段の照度分布は Fig.5 の通りであり、手寸 り照明の方がより均等な照度分布を表している。
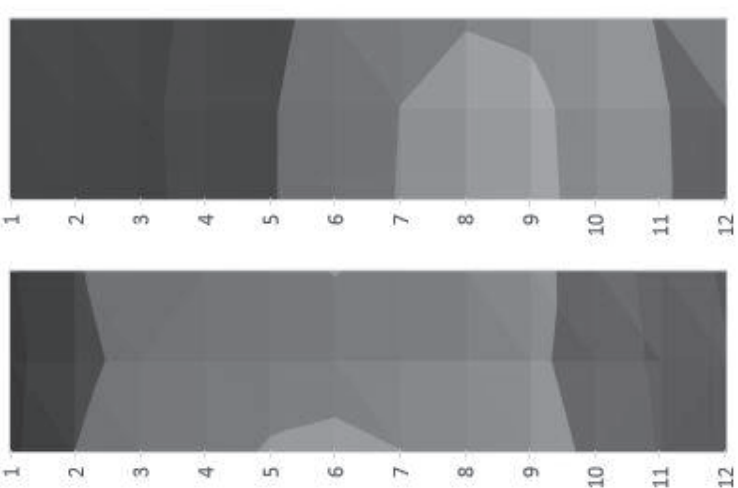

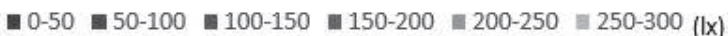

Fig. 5 Illuminance distribution of ceiling lighting(top) and handrail lighting(bottom)

なお、輝度カメラで撮影した輝度画像からの輝度分布は Fig.6 の 通りである。手すり照明の条件の場合、階段の段部がより明るく照 らされていることが示されている。

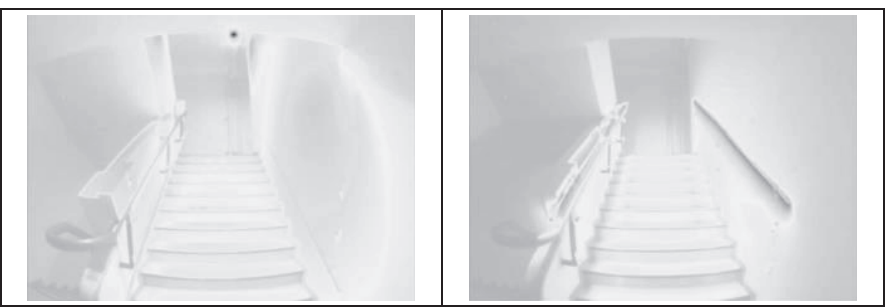

Fig. 6 Luminance distribution of ceiling lighting (left) and handrail lighting (right)

天井照明と手寸り照明の電力消費量を「100lx あたりの消費電力」 に換算して比較検討した結果は Fig. 7 の通りである。「天井照明」 の消費電力は $28.1 \mathrm{~W}$ 、「手すり照明の消費電力は $10 \sim 12.2 \mathrm{~W}$ の分布 を表しており、LED「手すり照明」の適用により、「天井照明」に 比べ、約 6 割の節電効果があることが分かった。

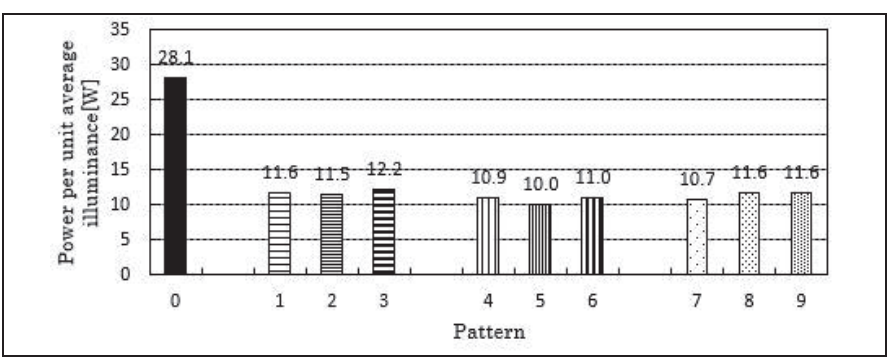

Fig. 7 Power per unit average illuminance of each pattern

\section{(2) 印象評価の結果}

印象評価項目の構成は Table3 の通りであり、評価基準を上り口、 
降り口に立って評価する「停止評価」、実際に上ってみて、下ってみ てから評価する「移動後評価」上り下りしてみてからの「総合評価」 に分け、両極 7 段階評価尺度を用い、印象評価を実施した。特に、 照明方式の質的評価のために「高級感」などの空間雾囲気に関する 項目も追加した。

Table3 Structure of impression evaluation items

\begin{tabular}{|c|c|c|}
\hline $\begin{array}{l}\text { Evaluation } \\
\text { criteria }\end{array}$ & $\begin{array}{l}\text { Evaluation } \\
\text { object }\end{array}$ & Evaluation item \\
\hline \multirow{2}{*}{$\begin{array}{c}\text { Evaluation at } \\
\text { stop }\end{array}$} & $\begin{array}{l}\text { Look up from } \\
\text { the bottom of } \\
\text { the stairs }\end{array}$ & \multirow{2}{*}{$\begin{array}{l}\text { Brightness, } \\
\text { Glare, } \\
\text { Softness of light }\end{array}$} \\
\hline & $\begin{array}{l}\text { Look down from } \\
\text { the top of the } \\
\text { stairs }\end{array}$ & \\
\hline \multirow{2}{*}{$\begin{array}{l}\text { Evaluation at } \\
\text { after movement }\end{array}$} & $\begin{array}{l}\text { After going up } \\
\text { the stairs }\end{array}$ & \multirow{2}{*}{$\begin{array}{l}\text { Brightness for going up (down), } \\
\text { Easiness to going up (down), } \\
\text { Visibility of steps, } \\
\text { Do you care about shadows?, } \\
\text { Lighting appropriateness }\end{array}$} \\
\hline & $\begin{array}{l}\text { After going } \\
\text { down the stairs }\end{array}$ & \\
\hline $\begin{array}{l}\text { Comprehensive } \\
\text { evaluation }\end{array}$ & $\begin{array}{l}\text { After trying to } \\
\text { go up and down } \\
\text { the stairs }\end{array}$ & $\begin{array}{l}\text { Preference } \\
\text { Feeling of safety } \\
\text { Luxury } \\
\text { Warmth of light } \\
\text { Feeling of openness }\end{array}$ \\
\hline
\end{tabular}

両グループの評価結果から、「若年者」グループと「高齢者」グル ープの判断基準がそれぞれ異なっている傾向が見られ、両グループ の結果を比較するための検討を行った。停止評価および移動後評価 の場合、上からの評価と下からの評価に分けて行っており、本章で は下からの評価（見上げて、上がってみて）の結果を基準とし以下 の通りに記す。

停止評価の「見上げて」評価結果は Fig. 8 の通りであり、両グル ープの評価結果間に明確な差が見られている。特に「若年者」グル ープの場合、「天井照明」を非常に明るく評価しつつ、まぶしく評価 している傾向であるが、「高齢者」グループの場合、天井照明と手す り照明を両方明るく評価している傾向が見られており、どちらでも まぶしくないという傾向が見られた。

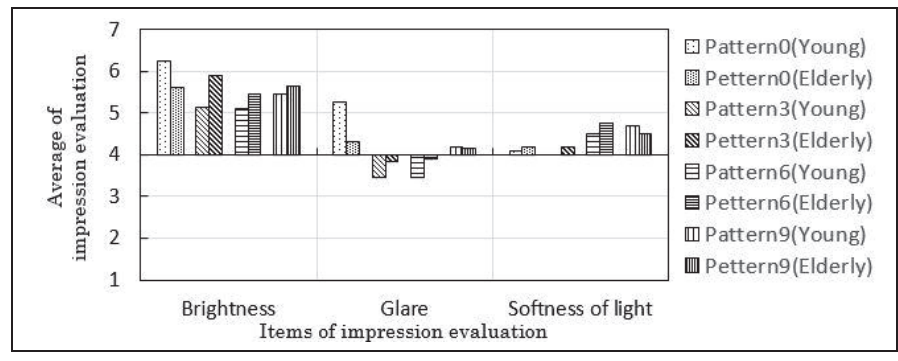

Fig. 8 Comparison of impression evaluation results (Young people and Elderly people : Evaluation at stop)

移動後評価である「上ってみて」の評価結果は Fig. 9 の通りであ る。「天井照明」に対しては「若年者」グループが、「手すり照明」 に対しては「高齢者」グループが高く評価している傾向が見られ、 「若年者」グループの場合、「天井照明」をより明るく評価している 反面、その判断基準が「照明の適切さ」の評価には反映されていな いと考えられる。なお、「若年者」グループは天井照明条件での影が 気になるという結果が見られた。

総合評価の「上り下りしてみて」評価結果は Fig. 10 の通りであ
り、空間の䨌囲気に関する「高級感」の評価において、両グループ の判断基準が大きく異なっている。「若年者」グループは天井照明の 高級感を非常に低く評価している反面、「高齢者」グループは天井照 明に対して手すり照明と同様な水準の高級感を感じていることが分 かった。

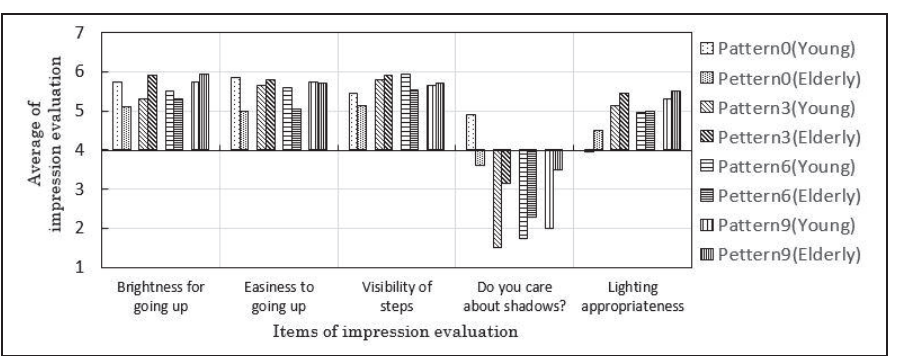

Fig. 9 Comparison of impression evaluation results

(Young people and Elderly people : Evaluation at after movement)

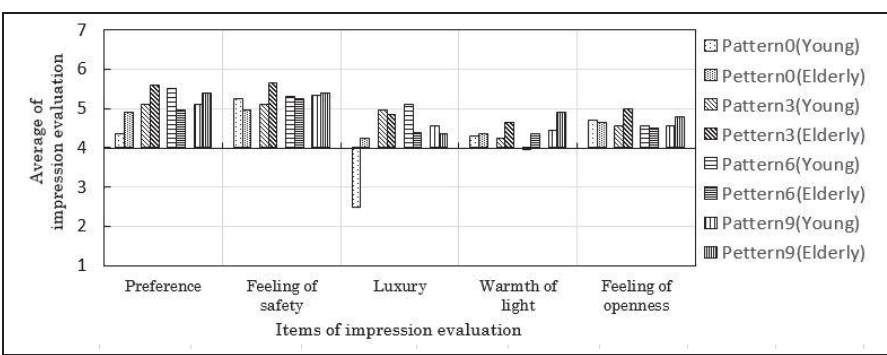

Fig. 10 Comparison of impression evaluation results (Young people and Elderly people : Comprehensive evaluation)

\section{(3) 統計分析の結果}

両グループの物理量と印象評価結果の相関検討結果は Table4 の 通りである。

「若年者」グループの場合、実験室の環境は環境要因が限られて おり、基本的に物理量に依存した評価が行われ、全般的な相関が高 くなっている。特に、「空間の明るさ」や「まぶしさ」の場合、物理 量との相関が高く見られている。

平均輝度の「上半分」と「下半分」から見ると、「明るさ」、「ま゙ しさ」の場合、「上半分」に依存して評価され、その他の項目は「下 半分」との相関が見られ、空間の明るさ評価に関しては、目線が上 の方、つまり空間全般を見ながら評価していることが分かった。

「高齢者」グループの相関の検討結果は、「若年者」の結果に比べ、 「鉛直面照度」との相関が小幅に低くなっており、「床面照度」や「平 均輝度」との相関は相当高くなっている。

特に「上半分」と「下半分」の平均輝度との相関係数を比較して みると、全評価項目にわたって「下半分」の平均輝度との相関が高 くなっており、「高齢者」グループの主な視対象は空間の下部、つま り階段の段部だと考えられる。

なお、目線前面の明るさである「鉛直面照度」が低いこと、特に、 移動後評価である「上るための明るさ」や「上りやすさ」との相関 が相当下落してしまうことも、階段利用時の高齢者は安全性や身体 的能力に対しての不安感があり、床面を注視しながら移動している のではないかと考えられる。 
Table4 Correlation analysis result between physical quantity and psychological quantity (*: significant)

\begin{tabular}{|c|c|c|c|c|c|c|c|c|c|c|c|c|}
\hline & & \begin{tabular}{|c|}
$\begin{array}{c}\text { Brightn } \\
\text { ess }\end{array}$ \\
\end{tabular} & Glare & $\begin{array}{r}\text { Brightness } \\
\text { for going up } \\
\end{array}$ & \begin{tabular}{|c|} 
Easiness to \\
going up \\
\end{tabular} & \begin{tabular}{|c|}
$\begin{array}{c}\text { Visibility } \\
\text { of steps }\end{array}$ \\
\end{tabular} & $\begin{array}{c}\text { Lighting } \\
\text { appropriateness } \\
\end{array}$ & Preference & \begin{tabular}{|c|}
$\begin{array}{c}\text { Feeling of } \\
\text { safety }\end{array}$ \\
\end{tabular} & Luxury & \begin{tabular}{|l|}
$\begin{array}{l}\text { Warmth } \\
\text { of light }\end{array}$ \\
\end{tabular} & \begin{tabular}{|c|}
$\begin{array}{c}\text { Feeling of } \\
\text { openness }\end{array}$ \\
\end{tabular} \\
\hline \multirow{6}{*}{ 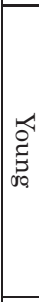 } & Vertical illuminance & $0.78 *$ & $0.75 *$ & \begin{tabular}{|l|}
$0.66 *$ \\
\end{tabular} & \begin{tabular}{|c|}
$0.66 *$ \\
\end{tabular} & $0.51 *$ & 0.23 & 0.29 & \begin{tabular}{|l|}
$0.62 *$ \\
\end{tabular} & -0.20 & $0.54 *$ & $0.65 *$ \\
\hline & Floor illuminance & $0.92 *$ & $0.89 *$ & $0.85 *$ & $0.83 *$ & $0.69 *$ & $0.52 *$ & $0.53 *$ & $0.84 *$ & 0.01 & $0.75 *$ & $0.86 *$ \\
\hline & $\begin{array}{l}\text { Average luminance } \\
\text { (Overall) }\end{array}$ & $0.87 *$ & $0.84 *$ & $0.87 *$ & $0.87 *$ & $0.81 *$ & $0.71 *$ & $0.68 *$ & $0.88 *$ & 0.32 & $0.76 *$ & $0.88 *$ \\
\hline & $\begin{array}{c}\text { Average luminance } \\
\text { (Upper half) }\end{array}$ & $0.85 *$ & $0.79 *$ & $0.73 *$ & $0.67 *$ & $0.51 *$ & 0.29 & 0.28 & $0.70 *$ & -0.29 & $0.67 *$ & $0.73 *$ \\
\hline & $\begin{array}{l}\text { Average luminance } \\
\text { (Lower half) }\end{array}$ & $0.69 *$ & $0.69 *$ & $0.76 *$ & $0.79 *$ & $0.79 *$ & $0.78 *$ & $0.75 *$ & $0.79 *$ & $0.57 *$ & $0.65 *$ & $0.77 *$ \\
\hline & Brightness & $0.93 *$ & $0.88 *$ & $0.92 *$ & $0.92 *$ & $0.85 *$ & $0.73 *$ & $0.70 *$ & $0.92 *$ & 0.31 & $0.81 *$ & $0.93 *$ \\
\hline \multirow{6}{*}{$\begin{array}{l}\frac{102}{2} \\
\frac{8}{8} \\
\frac{8}{4}\end{array}$} & Vertical illuminance & $0.67 *$ & $0.65 *$ & $0.54 *$ & $0.49 *$ & $0.53 *$ & $0.47 *$ & $0.56 *$ & $0.53 *$ & $0.57 *$ & $0.50 *$ & $0.62 *$ \\
\hline & Floor illuminance & $0.85 *$ & $0.85 *$ & $0.78 *$ & $0.73 *$ & $0.73 *$ & $0.70 *$ & $0.78 *$ & $0.75 *$ & $0.77 *$ & $0.72 *$ & $0.80 *$ \\
\hline & $\begin{array}{l}\text { Average luminance } \\
\text { (Overall) }\end{array}$ & $0.91 *$ & $0.86 *$ & $0.90 *$ & $0.88 *$ & $0.88 *$ & $0.84 *$ & $0.91 *$ & $0.89 *$ & $0.90 *$ & $0.87 *$ & 0.91 \\
\hline & $\begin{array}{l}\text { Average luminance } \\
\text { (Upper half) }\end{array}$ & $0.72 *$ & $0.76 *$ & $0.61 *$ & $0.54 *$ & $0.54 *$ & $0.56 *$ & $0.61 *$ & $0.56 *$ & $0.57 *$ & $0.59 *$ & $0.66 *$ \\
\hline & $\begin{array}{l}\text { Average luminance } \\
\text { (Lower half) }\end{array}$ & $0.82 *$ & $0.73 *$ & $0.86 *$ & $0.87 *$ & $0.87 *$ & $0.81 *$ & $0.87 *$ & $0.87 *$ & $0.88 *$ & $0.83 *$ & $0.85 *$ \\
\hline & Brightness & $0.95 *$ & $0.89 *$ & $0.92 *$ & $0.89 *$ & $0.89 *$ & $0.86 *$ & $0.92 *$ & $0.91 *$ & $0.91 \%$ & $0.88 *$ & $0.93 *$ \\
\hline
\end{tabular}

\section{(4) 実験 1 のまとめ}

「若年者」グループの印象評価結果、「天井照明」をより明るく評 価しているが、「見上げて」の評価場合、天井照明の条件まぶしく感 じていることが分かった。「高齢者」グループの印象評価結果、停止 評価の場合は、「若年者」グループに比べて条件による差が少ないが、 全般的に「手寸り照明」に対しての評価がより良い結果となってい る。特に、「段差のみや寸さ」や「上り下りや寸さ」などから大きな 差が見られた。

相関の検討の結果、「若年者」と「高齢者」グループの階段利用時 の視対象が異なっていることが分かった。若年者は段部より空間全 般を、高齢者は階段の段部を注視しながら評価する傾向が見られ、 今後の駅階段の照明設計にこのような結果が参考になると考えられ る。

\section{4. 室内実験 2}

室内実験 1 から、「手寸り照明」と「天井照明」の比較検討を行 い「手すり照明」の設置により階段の段部を明るく照らすとともに、 まぶしくない快適な照明環境の構成が可能であることが分かった。

しかし、階段に利用者がいる時を想定すると、側面に設置される 「手すり照明」の特性上、その性能が大きく低下寸る可能性がある ため、現場への適用を目標とし、階段が利用者で込んでいる条件で の実験を行った。

\section{1 実験の概要}

実験条件の構成およびその全景は Fig. 11 の通りであり、階段上 の人数条件は人との間隔が 4 段間隔の 4 人、 3 段間隔の 6 人、 2 段 間隔の 8 人、 1 段間隔の 10 人条件の 4 条件に構成した。

照明条件の場合、実験 1 の 10 条件の中で、現行の JIS 照度基準 上の $\mathrm{A}$ 級駅舎の階段に該当する 200lx の条件の夕採用し、天井照明 の条件や手すり照明の 3 条件（設置高さ $500 \mathrm{~mm} 、 800 \mathrm{~mm}$ 、 1,100mm）を含む条件 $0 、 3 、 6 、 9$ の 4 条件とした。被験者は 20 ～30 代の若年者を対象とし、条件ごとに 19 名〜 23 名の被験者から の評価を行った。なお、評価項目は室内実験 1 と同様な項目を活用 し、結果を直接的に比較できるような構成とした。

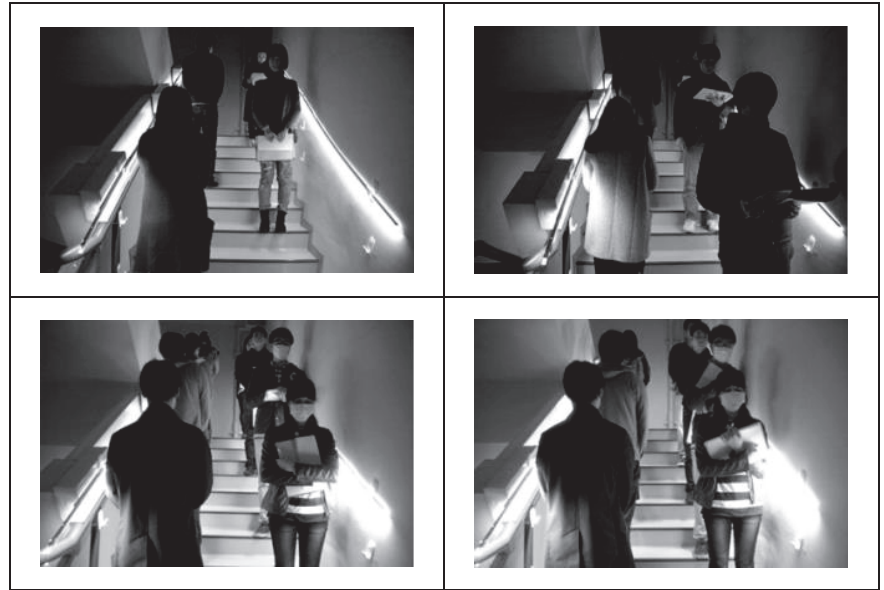

Fig. 11 Patterns by number of people $(4,6,8,10$ people)

\section{2 実験 2 の結果}

(1) 物理量の実測結果

照明条件別の床面照度測定結果は Fig. 12 の通りである。階段上 に滞在する人の増加により、「天井照明」に比べ「手すり照明」の平 均床面照度の方がより大きく落ちており、階段が込んでいる条件で は「手すり照明」の明るさの損失が大きくなることが分かった。

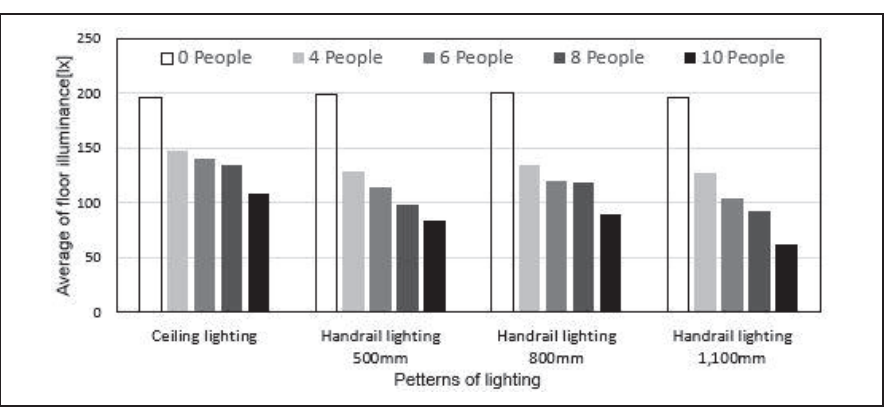

Fig. 12 Floor surface illuminance of each pattern

11 段構成の階段の各段の床面照度測定結果から標準偏差の検討 を行った結果は Fig.13 の通りである。「天井照明」の場合、人数の 増加による「標準偏差」の值が 50 前後を表しており、床面に照ら 
される光の量のばらつきが大きくなっていることが分かった。その 反面、「手すり照明」の場合、全般的に 30 以下の水準を表しており、 人の存在によらず均等な光環境となっていることが分かった。

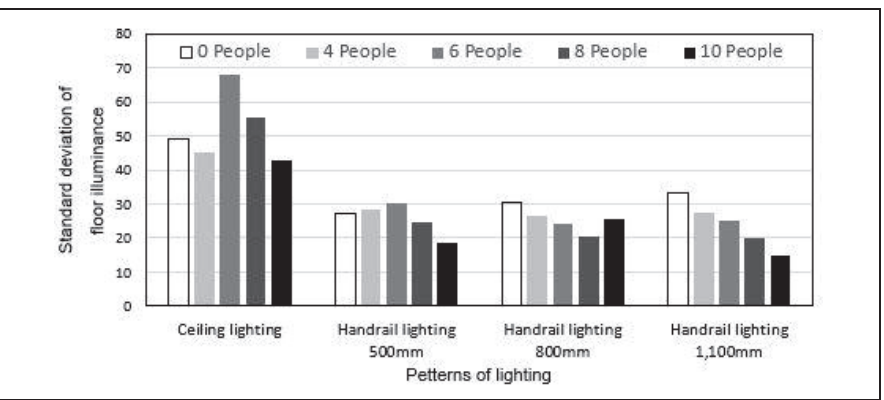

Fig. 13 Standard deviation of floor illuminance of each pattern

\section{(2) 印象評価の結果}

各人数条件および照明条件による印象評価結果は以下の通りであ る。「0人」条件の場合、室内実験 1 の「若年者」グループのデータ を基準とし、人数増加による印象評価結果の変動を検討した。

なお、本文には人数増加による影響が他条件に比べ少ない「6人」 条件を除いた「 0 人」、「4人」、「 8 人」、「10人」の 4 条件の結果を 中心とし、評価項目は「見上げた」の 3 項目、「上って見て」の 5 項目の評価結果を代表值としてピックアップし、以下の通りに記す。

\section{(1) 0 人条件の結果}

$\ulcorner 0$ 人、見上げて」の評価結果は Fig. 14 の通りであり、「明るさ」 や「まぶしさ」の評価結果が「天井照明」の方がより高くなってい る。移動後評価である「上がってみて」の場合（Fig. 15）、「上るた めの明るさ」に関しては「天井照明」の方が高く、それ以外の項目 に関しては「手すり照明」の方が高くなっている。

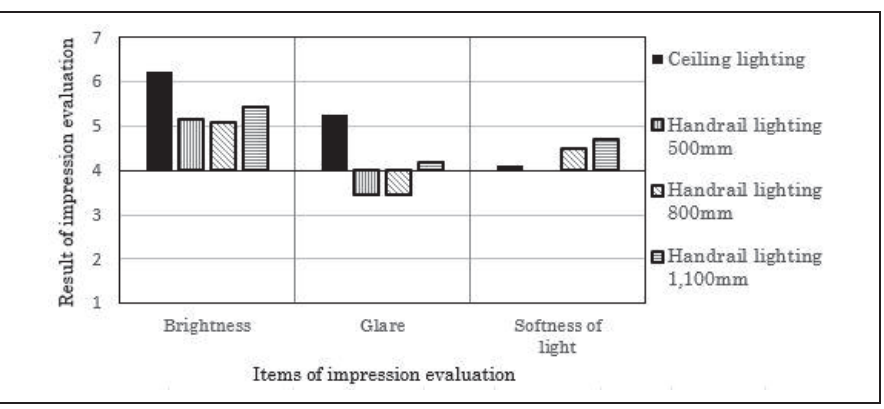

Fig. 14 Impression evaluation result of 0 person pattern (Look up)

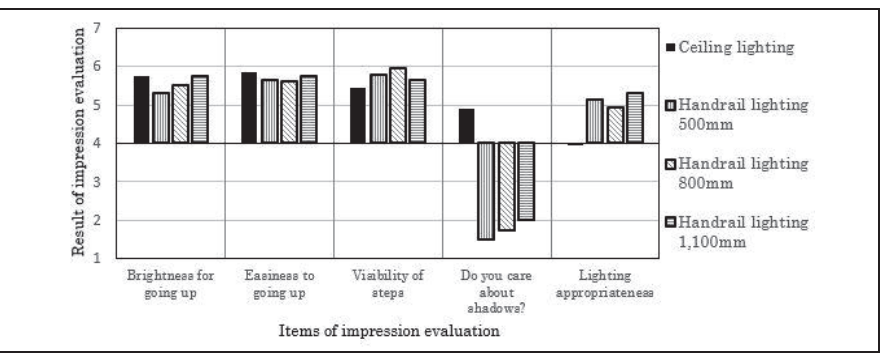

Fig. 15 Impression evaluation result of 0 person pattern (After going up)

\section{(2) 4 人条件の結果}

階段上に利用者がいることにより「手すり照明」を中心に「明る さ」が大幅に落ちている傾向が見られ（Fig. 16）、空間の床面照度 の低下により、「上り口」の地点から暗い印象を受けていると考えら れる。

その反面「天井照明」の場合、人数の増加による印象の低下が少 なく、人数が増えても下から見た空間の「明るさ」には差が少ない 傾向が見られた。

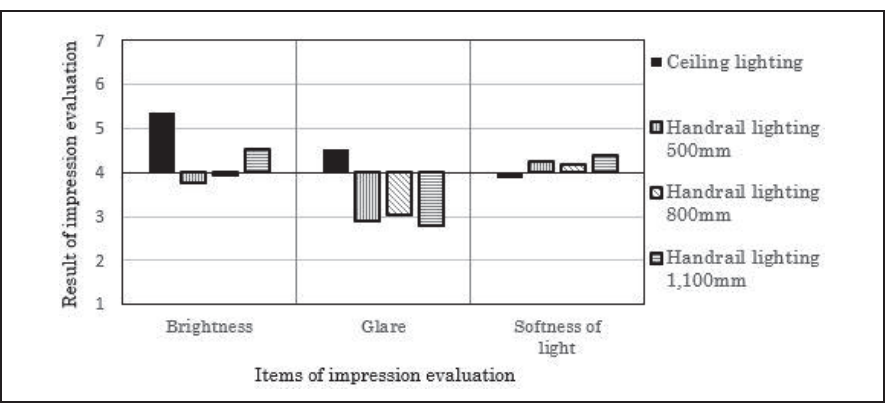

Fig. 16 Impression evaluation result of 4 people pattern (Look up)

移動後評価（Fig. 17）の「上るための明るさ」の場合、「天井照 明」の方が高く評価されており、「手すり照明」の場合、設置高さに よる差が見られた。特に、手すり照明の設置高さが高いほど明るく 感じられており、階段上に人がいる条件で床面のみ明るく照らされ ている「設置高さ $500 \mathrm{~mm} 」$ の条件に対しては、他条件に比べ暗く 感じられていると考えられる。

なお、停止評価での明るさに関しては「手すり照明」の方が低い が、実際に移動してみてからの評価項目の「上りや寸さ」や「段差 の見やすさ」などに関しては、「手すり照明」に対しての評価が高い 傾向が見られている。

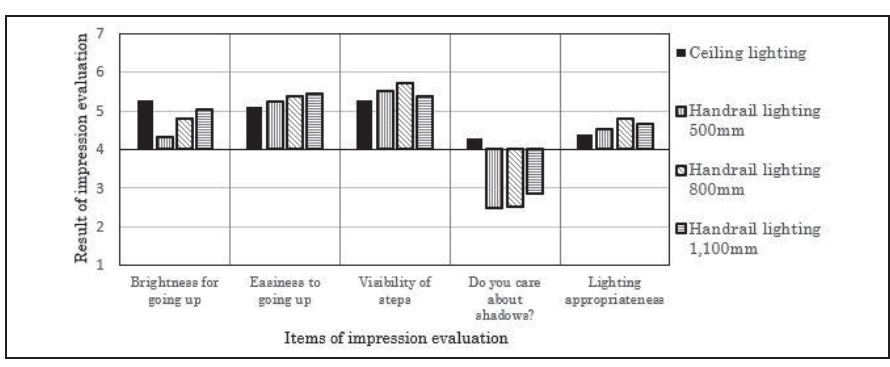

Fig. 17 Impression evaluation result of 4 people pattern

(After going up)

\section{(3) 8 人条件の結果}

8 人条件での「見上げて」の評価結果 (Fig. 18) は 4 人条件と同 様な傾向を表しており、「天井照明をより高く評価している反面、「移 動後評価」（Fig. 19）の「上ってみて」の評価結果からは傾向の変 動が見られた。

特に、「手すり照明」に対しての「段差の見やすさ」評価值が「天 井照明」に比べ大きく上回っており、階段上の人の密度が非常に高 くなる 2 段間隔の「8 人」条件からは判断基準に変化があったと考 


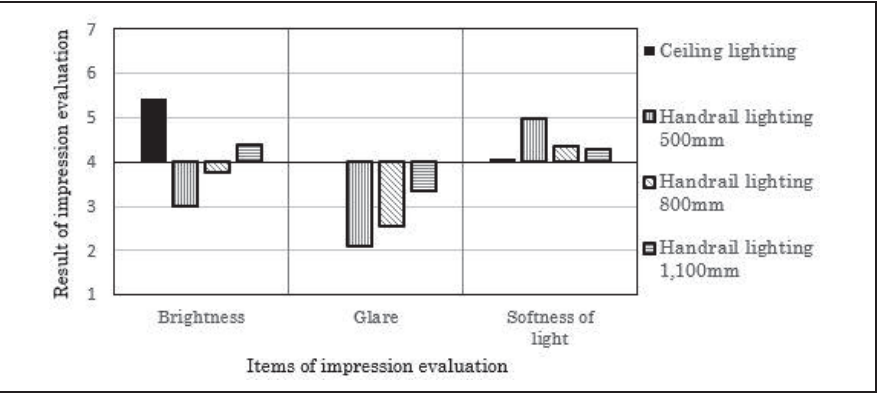

Fig. 18 Impression evaluation result of 8 people pattern

(Look up)

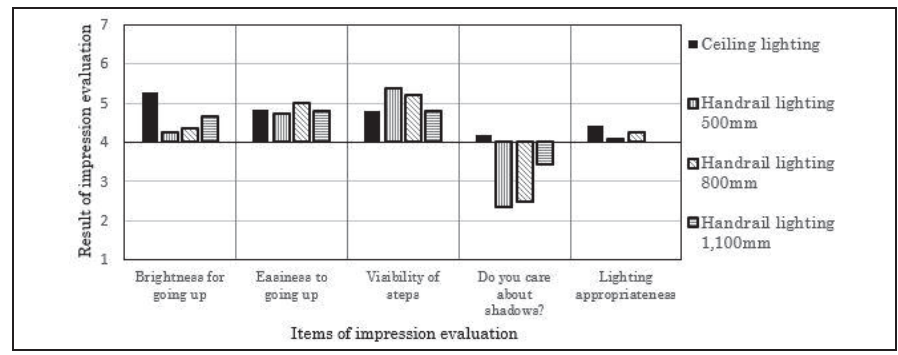

Fig. 19 Impression evaluation result of 8 people pattern

(After going up)

\section{(4) 10 人条件の結果}

階段上に人が多く、非常に複雑な条件を想定した「10人」条件の 「見上げて」評価（Fig.20）の場合、その傾向は「4人」、「8人」 条件と同様であり、天井照明をより明るく評価している傾向が見ら れた。

その反面、移動後評価である「上ってみて」評価の結果は Fig. 21 の通りであり、「上りやすさ」の場合、「手すり照明」に対しての 評価值が設置高さの $500 \mathrm{~mm}$ 条件を中心にやや高くなっている。な お、「段差の見やすさ」の場合、「手寸り照明」の方が非常に高く評 価されており、混んでいる条件での評価においては「手すり照明」 に対しての全般的な印象が高くなることが分かった。実際に動いて みてからの評価結果からこういう傾向が見られているのは、人数が 増えて階段上の人の密度が高くなるほど、利用者は空間全般より、 階段の段部の方（下段）に注目して評価を行っているのが原因だと 考えられる。

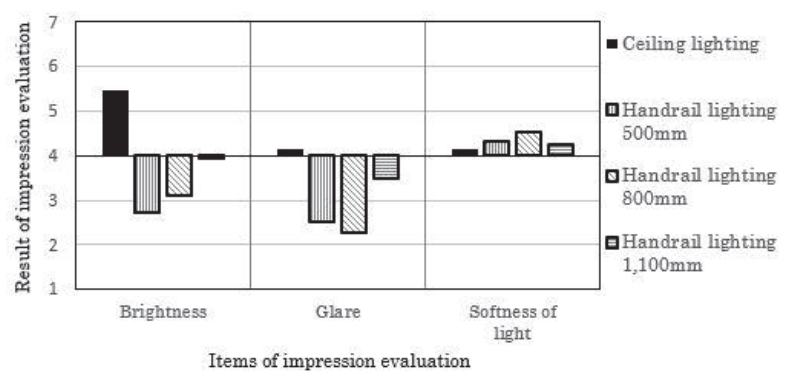

Fig. 20 Impression evaluation result of 10 people pattern (Look up)

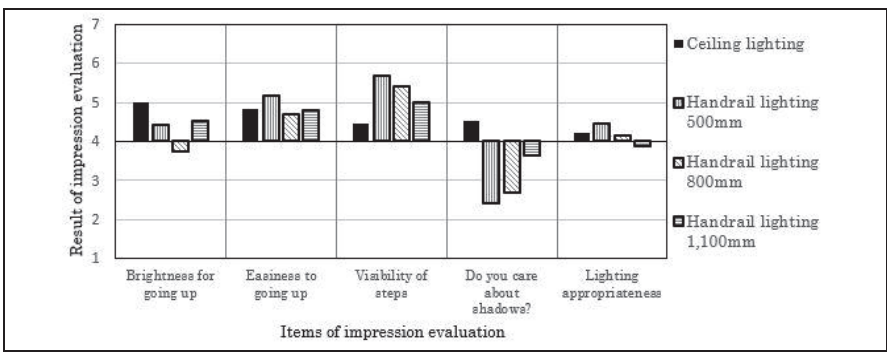

Fig. 21 Impression evaluation result of 10 people pattern

(After going up)

\section{(3) 実験 2 のまとめ}

階段上に人が滞在している場合、「天井照明」に比べ、「手すり照 明」の環境での物理的な変化が大きく、人数の増加による床面照度 の低下が大きくなることが分かった。

しかし、「天井照明」と「手すり照明」条件での照度分布から検討 した結果は Fig.22（6 人条件基準）の通りであり、「手寸り照明」は 人の影が発生しにくいため、より均等な光環境となっていることが 分かった。

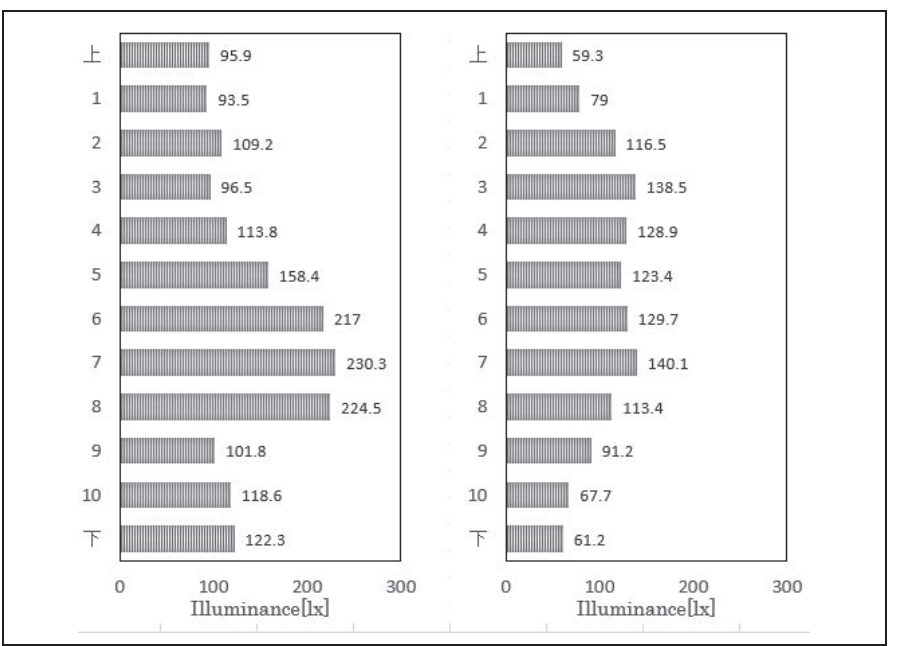

Fig. 22 Comparison of Illuminance Distribution of Stairs 6 persons pattern: ceiling lighting(left) v. handrail lighting(right)

\section{5. まとめ}

室内実験 1 の結果に基づき、同様な照度（2001x）の環境であっ ても階段の段部を明るく照らす照明手法により、空間の印象を高め ることができると考えられる。特に、駅空間の階段で問題となって いる「グレア」や影による不均等な照度分布などを「手すり照明」 の設置により改善することは有効だと考えられる。

年齢層により、視対象や階段利用時の注目対象が異なっているが、 どちらのグループでも段差の見やすい「手すり照明」の環境を快適 に評価する傾向が見られており、より明るく安全な階段の照明環境 の構成が可能であると考えられる。

消費電力の検討による手すり照明の節電性能は、100lx あたりの 消費電力基準、「天井照明」に比べ、約 6 割の節電効果があり、節 
電方法としても、合理的だと考えられる。

人数の増加による「手すり照明」の照度量の低下は避けられない と考えられる。照明の位置が低くなっており、階段を通る人の影響 を受けやすいため、全般的に照度が低くなっていると考えられる。

停止位置で見た印象と、実際に階段を利用してみてからの印象が 異なっており、「停止評価」では「天井照明」の方が高く評価された が、「移動後評価」の場合評価傾向が変わり、「段差の見やすさ」や 「照明の適切さ」を中心に「手すり照明」に対しての評価が高くな ることが分かった。

このような階段「手すり照明」は、天井がない階段、天井高が非 常に低いか非常に高い場合、照明の設置位置が限定される場合など に対して適用できると考えられる。

なお、主照明の設置位置を天井ではなく目線より低くすることに より、グレアの防止や段部をより明るく照らすことができると考え られる。また、壁面を照らす線光源の活用により、光の均等性の確 保ができ、より安全な光環境の構成に成ると考えられる。

ただし、今後の課題としては、「手すり照明」をメイン照明として 活用する場合、暗くなっている空間上部を照らすサブ照明が必要と なり、「天井照明」との適切なバランスを検討する必要があると考え られる。

\section{謝辞}

本研究を進行するにあたり、ご協力いただいた株式会社遠藤照明、 および同社鈴木直行氏に謝意を表します。

\section{参考文献}

1) Kimura, O.: How to proceed with measures to save electricity by local governments, Central Research Institute of Electric Power Industry, 2011

木村 宰: 地方自治体による節電対策の進め方, 電力中央研究所, 2011

2) Koga, T. et al: A Study of User Evaluation of The Lighting Environment on Station Platforms Through Comparison between Under and After Power saving Conditions, Journal of Environmental Engineering (Transactions of AIJ), Vol. 78, No. 688, pp. 445-452, 2013. 6

3) ITOH Daisuke: Field Investigation on Electricity Saving Lighting in Stations $(<$ Special Issue $>$ Learning from the Great East Japan Earthquake : Lighting for the Elderly and People with Low Vision), Journal of the Illuminating Engineering Institute of Japan, Vol. 96, No. 4, pp. 214-216, 2012

4) IZUMI Yasuhiko: Improve utilization of station energy, Railway Technical Research Institute, The 25th Lecture, pp. 41-48, 2012 伊積 康彦：駅の節電状況の実態調査, 第 25 回鉄道総研講演会, pp. 41-48, 2012

5) A Comprehensive Strategy for the Rebirth of Japan: Exploring the frontiers and building a "Country of Co-creation", Cabinet Office, Government Of Japan, 2012 日本再生戦略：フロンティアを拓き共創の国へ，2012

6) NAGATA Tadashi: Railway Business Capital Investment Plan, Keio Corporation, 2016

永田 正：2016 年度の鉄道事業設備投資計画，京王電鉄株式会社，2016

7) Fire Prevention Council: The way of fire protection safety measures of terminal facilities to be compounded, Tokyo Fire Department, 2012 火災予防審議会：複合化するターミナル施設の防火安全対策のあり方, 東京消防庁，pp. 17-40，2012

8) JIS Z 9110, Japanese Industrial Standards Committee, 1958

9) JIS Z 9110, Japanese Industrial Standards Committee, 1960

10) JIS Z 9110, Japanese Industrial Standards Committee, 1964

11) JIS Z 9110, Japanese Industrial Standards Committee, 1969

12) JIS Z 9110, Japanese Industrial Standards Committee, 1975

13) JIS Z 9110, Japanese Industrial Standards Committee, 1979

14) JIS Z 9110, Japanese Industrial Standards Committee, 2010 


\title{
A STUDY ON APPLICABILITY OF HANDRAIL LIGHTING IN STAIRS SPACE OF RAILWAY STATION
}

\author{
Jaeyoung HEO ${ }^{* 1}$, Yoko UCHIDA ${ }^{* 2}$, Kyungsun $C H U N G^{* 2}$, \\ Miki KOZAKI ${ }^{* 3}$, Takaaki KOGA ${ }^{* 4}$ and Kotaroh HIRATE ${ }^{* 5}$

\footnotetext{
${ }^{* 1}$ Researcher, Dept. of Architecture, Graduate School of Eng., The Univ. of Tokyo, Dr.Eng.

${ }^{* 2}$ Former Grad. Student, Dept. of Architecture, Graduate School of Eng., The Univ. of Tokyo, M.Eng.

${ }^{*}$ Assist. Prof., Faculty of Core Research, Natural Science Division, Ochanomizu University, Dr.Eng.

${ }^{*}$ Prof., Dept. of Architecture, Graduate School of Eng., The Univ. of Tokyo, Dr.Eng.
} \\ ${ }^{*}$ Assoc. Prof., Faculty of Regional Design, Dept. of Architecture and Urban Design, Utsunomiya Univ., Dr.Eng.
}

The first purpose of this study is to clarify the influence of light environment on user's evaluations of stairs such as visibility and easiness of moving up and down. By measuring illuminance, brightness, and subjective evaluations of stairs of stations, it shows that illuminance and brightness of the lower view angle influence greatly on subjective evaluations. Taking that result, we conclude that lighting set in handrails of stair can illuminate most efficiently.

The second purpose is to clarify the influence of variation of lighting height. Intended for elderly people and young people, we conducted an experiment. As a result, variation of height of handrail lighting does not influence on subjective evaluations greatly. However, the evaluations in the environment of handrail lighting tend to be higher than that of ceiling lighting. In addition, it shows that elderly people can feel security in the environment of handrail lighting. 